\title{
Constructing difference in Japan: Literary counter-images of the Okinawa boom*
}

INA HEIN

Abstract

This article's approach is indebted to the method of discourse analysis from a cultural studies' perspective. It attempts to position and analyze literary texts by four authors from Okinawa - Medoruma Shun (*1960), Matayoshi Eiki (*1949), Akahoshi Toshizō (*1974) and Tefu Tefu P. (*1976) - in the context of the Okinawa boom which has flooded Japanese popular culture and mass media since the 1990s. It will be shown that these writers clearly position themselves against the Okinawa boom. On the one hand, the texts selected for analysis in this paper construct Okinawa as a 'different Japan' - just like the images created by Japanese mass media and popular literature on the main islands. On the other hand, though, the authors subvert the mainstream discourse on 'Okinawan difference': Medoruma addresses inconvenient topics which otherwise remain excluded from popular images of Okinawa and, at the same time, highlights Okinawa's inner diversity, thus destabilizing the idea of 'one Okinawan identity'. Matayoshi stays ambivalent in creating Okinawa as a space which is culturally different from Japan: His text abounds with markers for Okinawan-ness, but at the same time his main character keeps an ironic distance to 'Okinawan traditions'. Akahoshi and Tefu Tefu eventually pick up prevalent topoi from mainstream discourse and turn them into their opposites.

Keywords: Okinawa; difference; diversity; contemporary Japanese literature; Medoruma Shun; Matayoshi Eiki; Akahoshi Toshizō; Tefu Tefu P.

\section{Introduction}

Since the 1990s, the tendency among minorities to stress their own ethnicity has been growing worldwide. At the same time, these minority groups have started to demand and have indeed gained better access to means of self-representation. Japan is no exception here: a growing eth- 
nic (but also social) diversity within Japanese society is increasingly being acknowledged and discussed publicly. Whether this newly felt plurality actually goes along with a true acceptance of differences by the majority is disputable, though. If that is the case, this would indeed be evidence that the long held self-perception of Japan as being an ethnically and culturally homogenous state ${ }^{1}$ is gradually starting to dissolve.

The denial of the existence of (ethnic, cultural or even social) internal differences from the official image of Japan used to be accompanied by a negative, discriminating view of those being perceived as 'different'. Okinawa can serve as an interesting example here: For the longest time since its affiliation to Japan it has been considered underdeveloped and uncultivated. In the 1990s, though, a downright Okinawa boom took hold of Japanese popular culture and mass media, and more positive images of Okinawa began to spread on a large scale. ${ }^{2}$ These, however, are being increasingly criticized for heavily relying on exoticism and stereotypes (Iwabuchi et al. 2004), while at the same time the prefecture's problems (which first and foremost derive from the Pacific War and the subsequent U.S. occupation) are completely obscured. On the other hand, representations of a specific 'Okinawan-ness' by Okinawan intellectuals, writers, filmmakers etc. have increased since the mid-1990s; these generally demonstrate a critical stance of Japanese conceptions of Okinawa which primarily focus on a soft sell. ${ }^{3}$ One could well say that the hegemonic discourse on 'Okinawan difference' is monopolized by the Japanese mass media, while, at the same time, counter-discourses the expression of minor voices - do exist as well, even if they can mostly be found in different kinds of media such as independent film or literary works.

In this paper, I want to take a closer look at a small sample of such counter-discourses by analyzing the strategies four Okinawan authors employ in constructing Okinawa as a 'different Japan': Medoruma Shun $\left({ }^{*} 1960\right)$ and Matayoshi Eiki $\left({ }^{*} 1949\right)$ who both were awarded the Akutagawa Prize in the 1990s, as well as Akahoshi Toshizo $\left({ }^{*} 1974\right)$ and Tefu Tefu P. $(* 1976)$ who won major regional literary prizes in 2004 and 2000 respectively. The epistemological interest of this paper, however, is not a literary one in a narrow sense: I rather treat constructions of Okinawa in the fictional texts as part of a broader discourse on difference in contemporary Japan and as a site for an ongoing struggle about representation.

\section{Context: Okinawa between foreignness and sameness}

Until the end of the Edo period (1600-1868), Okinawa - then the Ryūkyū Kingdom and an important center for the trade of luxury goods in 
the Asia-Pacific region - was formally positioned outside Japan. In 1609, the Shimazu-Clan from the Satsuma domain in Southern Kyūshū brought the Kingdom under its control. Ryūkyū nevertheless continued to be a part of the Chinese tributary system, so that a period of "dual subordination" (Taira 1997: 141) began. That way, Satsuma and the Tokugawa Shogunate were able to participate in Asia-Pacific trade activities despite Tokugawa's isolation policy. Still, a cultural assimilation of Ryūkyū was not yet demanded, on the contrary: "Throughout the eighteenth and nineteenth centuries, Satsuma insisted that the Ryūkyū Kingdom was a foreign (and 'barbarian') land, forbade Okinawans from wearing Japanese clothing or adopting Japanese names, and required tribute payments to Satsuma" (Hein and Selden 2003: 9).

Officially, Ryūkyū was incorporated into the modern Japanese state when in 1872 the Kingdom was first turned into a Japanese domain (han) and seven years later into Okinawa Prefecture (Taira 1997: 153157; Yonetani 2000; Uemura 2003). This course of events and Okinawa's subsequent Japanization is referred to as "annexation" or as "colonization" by scholars like Taira Kōji (1997), Uemura Hideaki (2003) or Oguma Eiji (2006 [1998]). Since "the [Edo-period] vision of a world made up of concentric circles, where foreignness increased the farther one moved from the center, came to be replaced by a vision of a single nation where 'development' and 'modernity' diminished the farther one moved from the capital toward the geographic extremities" (Morris-Suzuki 1998: 29), Ryūkyū's foreignness could now be explained in terms of its backwardness rather than its innate strangeness. This lead to two results in the discursive construction of Okinawa vis-à-vis Japan: First, a "theory of same origin" (nichi-ryū dōso-ron) was established, and Okinawa - which before had been imagined as a foreign country - "was declared "from time immemorial a constituent of Japan" (Yokoyama 1980: 278; as cited in Yonetani 2000: 15). Second, Okinawa was equated with Japan's own distant history, so much so that it became to be perceived as a "living museum of Japan's ancient past" (Siddle 1998: 127).

Ever since the Okinawans were made Japanese citizens by the end of the nineteenth century, there have been heated controversies about the prefecture's (cultural) identity - between difference from and sameness with Japan. While internal differences and hierarchies had, for a long time, been excluded from Japanese self-perception, by the 1990s cultural (and social) differences within Japanese society have become evident. This (seemingly) new diversity in contemporary Japan might still be rejected because of its potential threat to the established order. John Maher (2005), however, takes up the position that ethnic differences in Japan are not necessarily accompanied by exclusion anymore. Referring to statements made by young people of Japanese-Korean, Ainu, or Okina- 
wan descent, he shows that "being different" has rather come to bear positive connotations and may even be perceived as desirable - or "cool" (Maher 2005: 90).

As a matter of fact, in the specific case of the discourse on Okinawan difference, a paradigm shift from negative (stigmatizing) to positive (idealized) representation can clearly be observed. In the Meiji period (1868-1912), Japan constructed itself as a modern and civilized state, while, at the same time, the Okinawans were perceived as backward, poor, uncultivated, lazy, uneducated, and hedonistic - all of which made them appear to be not really trustworthy Japanese citizens. The differences which were ascribed to the Okinawan population, consequently, were interpreted as "marks of inferiority" (Hein and Selden 2003: 10). Even today, Okinawa holds several sad records: It remains Japan's poorest prefecture (average yearly incomes are only 70 percent of those on the main islands) with the highest unemployment rate (about $8 \%$, which is twice the rate of mainland Japan) and the lowest educational level. In addition, it still suffers from the burden which was imposed on the islands by the national government after the end of the Pacific War: About 70 percent of all American military facilities in Japan are located in Okinawa, an area less than 1 percent of the total of Japan.

However, the negative image of Okinawa has undergone a massive change in the past decades. At present, Okinawan 'difference' is being conceived positively and marketed (and consumed) accordingly. The Okinawa boom of the past decades covers many different areas": Okinawan music and food have come into vogue; Okinawa has been discovered as a southern island paradise by the Japanese tourism industry, and each year about 25,000 Japanese, who try to free themselves from the restraints and pressures of Japanese everyday life, move to Okinawa (Tōkeikyoku 2008). From the 1990s onwards, Okinawa has also served as an exotic setting in a continuously growing number of films, literary works, and, since the year 2000 , television series ${ }^{5}$.

\section{Imagining the 'other': Japanese constructions of Okinawan difference}

Japanese mainstream media productions as well as popular literature usually employ a certain set of elements from Okinawan everyday culture and folklore to visualize its 'otherness'. Often, a light dose of socalled uchinäguchi (the Okinawan language) - accompanied by explanations for a Japanese audience - is used to distinguish Okinawa from Japan. Okinawa is constructed as a place where spirituality and 'traditions' are kept alive, like, for example, special forms of ancestor worship or certain rituals performed by female shamans called yuta. 
Moreover, Okinawa seems to be characterized by constant musical and festive activities; it is represented as a place inhabited by "cheerful and nice Okinawan people who enjoy singing, dancing and drinking" (Kō 2006: 156). The Okinawan characters are frequently depicted as relaxed, natural, informal, simple-hearted, and innocent. Here, communal structures (the village, the family) are still intact, and sometimes this kind of solidarity makes one forget the chronic lack of money - romanticizing Okinawa's economically desolate situation.

In these recent media productions and literary works, life in Okinawa seems to proceed snugly and unhurriedly. Okinawa is constructed as a peaceful island paradise - the fact that the landscape is largely dominated by military bases and endangered by Japanese construction projects is completely ignored. Experiencing this idealized Okinawan nature, which is represented in terms of exotic vegetation, blue sea, white beaches etc., ultimately leads to iyashi [i.e., spiritual and emotional healing] on the part of the Japanese characters.

Okinawa is thus being functionalized for Japan's interests, whereas the basic tenor is one of nostalgia (natsukashisa): Japan, which usually is equated with the Tokyo metropolitan area, stands for modernity and symbolizes coldness - including the aspect of interpersonal relationships - whereas in Okinawa (and in the Okinawan characters) something that Japan has already lost is preserved. Okinawa obviously is conceptualized as counter-image of a Japan which has been distorted by modernization, high economic growth and mechanization.

Okinawan culture, in some examples, is also constructed as a mix of Okinawan, Japanese, other Asian and even Western (U.S. American) elements. At first glance this seems to hint at the concept of hybridity, if understood as "everything which owes its existence to the mixing of traditions [...] everything that results from the techniques of collage and sampling" (Bronfen and Marius 1997: 14, my translation). Since in Japan's hegemonic self-perception after 1945 its (supposed) ethnic and social homogeneity is emphasized, this construction of cultural blending as an important attribute of Okinawan identity might further differentiate Okinawa from Japan. However, the cultural mix as expressed for example in Nakae Yüji's films such as Nabbi no koi [Nabbi's love] from 1999 or Hotel Hibiscus from 2003 seems to be nothing more than a trendy accessory - without the implications hybridity has in the context of postcolonial theory. After all, Okinawa's quasi-colonial past and the present consequences are kept as a blind spot in Japanese constructions of Okinawa. Bhowmik therefore calls the Okinawa boom the "latest type of colonization" (Bhowmik 2008: 3). 


\section{Change of perspective: Literature from Okinawa}

In the course of the Okinawa boom, an increasing number of writers from the Japanese main islands have chosen Okinawa as a setting in their literary texts (e.g., Mori 1989; Yoshimoto 2004; Okuda 2005). At the same time, the literary activities by authors from Okinawa happened to attract wider attention as well, since both Medoruma Shun and Matayoshi Eiki were awarded the prestigious Akutagawa Prize in the mid1990s. Of course, as more and more migrational activities can be observed between Okinawa and the Japanese main islands, it becomes increasingly difficult to determine who falls into the category 'Okinawan' and who does not. Moreover, the 'Okinawan descent' of an author itself might not be a very useful category in determining what 'Okinawan literature' (Okinawa bungaku) is: Just the bare fact that an author was born in Okinawa does not mean that he or she takes Okinawa up as a theme in his or her writing. At the same time, authors of 'Okinawan descent' do not necessarily represent a more 'authentic' Okinawa than those without; the images they create are still constructions, after all. Thus it is not surprising that attempts to grasp the term Okinawa bungaku (which might be translated as 'literature from Okinawa' as well as 'Okinawan literature') have tended to bear very different results so far. Okamoto Keitoku, for example, defines it quite narrowly as "writing executed in standard Japanese by authors of Okinawan descent who, taking Okinawa as a theme, pursue the issue of identity" (Okamoto Keitoku, as cited in Bhowmik 2008: 16). Yonaha Keiko, on the other hand, argues that Okinawa bungaku might be understood in broader terms, as "works by persons with the experience of having lived in Okinawa for some time" which focus on Okinawa (Yonaha 1996: 205) or are spatially located in Okinawa (Yonaha 2006: 5).

Just as there is no common understanding of what kinds of texts should be treated as Okinawa bungaku, there is also no consensus about the question how literature from Okinawa can be positioned within the broader frame of Japanese literature. ${ }^{6}$ I would like to suggest, though, that it should be seen, in any case, against a postcolonial background. As a matter of fact, the specific experiences resulting from Okinawa's quasi-colonial past have caused many local authors to create texts which differ from those by Japanese writers in certain ways. Recurring themes in literature by Okinawan authors are the Battle of Okinawa (including present-day war memories) as well as problems brought about by the U.S. occupation and the continuing presence of U.S. military bases in the prefecture. Since the mid-1990s, efforts to construct a specific 'Okinawan' cultural identity are also increasing. These approaches challenge the dominant notion of Japan's homogeneity and the non-existence of discrimination. 
In the following, I would like to discuss the construction of 'Okinawan difference' in literary texts by four writers who all happen to be of Okinawan descent in greater detail. In order to treat their texts as part of the counter-discourse of the Okinawa boom, criteria for selection were that they all had to deal with the topic of Okinawan cultural identity in one way or another and, at the same time, position themselves critically against the more popular images distributed by Japanese mainstream media and literature. In addition, all four selected are award-winning authors. However, Medoruma Shun and Matayoshi Eiki are known nation-wide and some of their works have been translated into English. Akahoshi Toshizo and Tefu Tefu P. are younger, less well-known writers and their works are so far only available in Japanese.

\subsection{Medoruma Shun: "Suiteki" and "Mabuigumi"}

Okinawan writer Medoruma Shun $\left({ }^{*} 1960\right)$ is regarded as a "provocative social critic" (Bhowmik 2003: 311) and a "public intellectual" (Molasky 2003: 161) who publishes his political essays in numerous local as well as national newspapers and magazines. In his fictional texts, he frequently refers to local color elements, like, for example, Okinawan dialect or local religious practices. Medoruma explicitly distances himself from the popular representations of Okinawa in Japanese mainstream media and comments on this as follows: "I think it's a poet's duty to destroy the image of 'Okinawa' the mass media produces, and represent his own 'Okinawa"' (Medoruma Shun, as cited in Bhowmik 2008: 145).

Although Medoruma belongs to a generation which has not experienced the Battle of Okinawa directly, in his narratives he often addresses the effects of the war (or wartime memories) on people in the present time. However, he does not depict his characters solely as victims but also treats feelings of guilt on the side of Okinawan characters as well. As representative texts for this approach, I chose the short story "Suiteki" [Droplets] from 1996, for which Medoruma was awarded the Akutagawa Prize in 1997, and "Mabuigumi" [Spirit recalling] from 1998, which won him the Kawabata Yasunari-Prize in 2000. Both texts are very similar in structure: Events are triggered by unexplainable incidents breaking into the protagonists' everyday lives, suddenly forcing them to grapple with hitherto repressed war memories and feelings of guilt.

"Suiteki" begins with its protagonist, the approximately 70 year old Tokusho, being seized with a strange sickness: He is unable to move, his leg is grotesquely swollen and while to his environment he seems unconscious he himself is very well able to notice everything that is happening around him. Tokusho's wife Ushi tries to cure him with traditional healing methods but is unsuccessful. At night the ghosts of 
wounded and disfigured soldiers start to appear in front of Tokusho and take turns in drinking from water which is dripping from his toe. It takes Tokusho some time to recognize the ghosts as his former war comrades and to identify his dead friend Ishimine among them. He finally remembers that he had broken his promise to bring Ishimine, who was heavily injured, water; instead, he had greedily drunk it himself and subsequently abandoned the friend who then died. Only when he begs Ishimine's ghost to forgive him and confesses that he had been suffering for the past fifty years, Ishimine talks: "Thank you. At last the thirst is gone" (Medoruma 2000 [1997]: 281; quotes are taken from the English translation). With this, the haunting is over, and Tokusho is cured.

In "Mabuigumi", the female protagonist Uta (who is about the same age as Tokusho in "Suiteki") is being confronted with strange occurrences as well: In the story's present set in contemporary Okinawa, she is called to the house of Kōtarō, the son of her friend Omito who died during the Battle of Okinawa (April 1st-June 22nd, 1945). Kōtarō's mabui [spirit] has separated from his body, ${ }^{7}$ leaving him so weak that a huge hermit crab has made itself a home in his mouth. Uta without avail endeavors to conduct certain ceremonies called mabuigumi in order to call the spirit back to its body. Her war memories surface when she observes an ocean turtle burying its eggs in the sand at the beach where Kotaro has lost his mabui. Only now the reader learns that Kotaro's mother Omito got shot during the Battle of Okinawa on the very same beach by patrolling Japanese soldiers while she was trying to dig out turtles' eggs in search of food - whereas Uta stayed behind in their hiding-place. After the end of the war she searches the beach for Omito's body as she had promised, but she is unable to find her dead friend. Helping to raise Kotarō henceforth for Uta is a way to atone at least a bit for the guilt she feels toward Omito (Medoruma 2000 [1999]: 35). The story ends with two prying reporters taking a picture of Kotaro's body; scared by the photoflash, the crab withdraws into his throat and causes him to suffocate.

The wartime account in "Mabuigumi" draws a clear dividing line between Okinawa and Japan: The Okinawan civilian population does not only have to flee from American troops, but must be aware of Japanese soldiers as well, since the latter might kill Okinawans on suspicion of espionage instead of protecting them (Medoruma 2000 [1999]: 32). As a matter of fact, there were innumerable cases in which the Imperial Japanese Army, during the Battle of Okinawa, suspected Okinawan civilians of having collaborated with the enemy and executed them for this reason.

In "Suiteki", references to the war and the subsequent American occupation can be found everywhere in the narrative's material present as 
well: Tokusho's cousin wears "pants with a sharp crease (obviously U.S. military surplus)" (Medoruma 2000 [1997]: 266), the protagonist's bed is described as "a steel-frame army cot" (Medoruma 2000 [1997]: 255), his wife grabs a machete from the shed to scare the villagers away from his sickbed (Medoruma 2000 [1997]: 257), and a "bus tour of the island's war memorials" (Medoruma 2000 [1997]: 259) is mentioned. Not only the wartime memories of the story's protagonist, but also the omnipresence of reminders of the Battle of Okinawa specify 'Okinawan difference' in this text. And it is exactly after-effects of the war like these Shinjo Ikuo addresses when he states that in the case of Okinawa the sengo [postwar] period might not have begun yet (Shinjo 2003: 5-9).

Both stories examine the central characters' lack of (self-critical) grappling with the past. In "Suiteki", the fact that Tokusho himself had survived causes heavy feelings of guilt. But he not only tries to push his memories aside, he even lies to himself and his environment as he reports on his wartime experiences in schools and adapts his accounts to what his audience wants to hear. Tokushō is thus a victim of the war on the one hand, but at the same time he also falls prey to his need for attention and recognition. Even though the ghost soldiers force him to face the past, in the end he misses the opportunity to free himself from his guilt and returns to his old habits. Molasky thus states: "["Suiteki"] offers a critique of Okinawans' desire for a relatively painless public memory of the war, the type of memory that permits cathartic tears without recurring nightmares" (Molasky 2003: 184).

'Okinawan difference' is not only expressed, though, in terms of the specific war experiences of Okinawan civilians as a discriminated minority who could easily be sacrificed by the Imperial Japanese army, or the ubiquity of the war on the Okinawan islands even in the present time: In both narratives, it is further reinforced by the stressing of distinctive cultural characteristics. Japanese mainstream media productions and literature frequently establish Okinawa's difference from Japan by the use of terms from its regional language(s). Usually, they are made easily accessible to a Japanese audience because instant translations or explanations are given - but Medoruma employs a different technique in his texts, leaving Japanese readers uncertain about the meaning of the Okinawan terms he uses.

Constructions of Okinawa as its own world which centers around ghosts, ancestors, family matters etc., and which stands in contradiction to the "scientific 'modern' Japanese world" (Allen 2002: 224) can often be found on the mainstream level of discourse. Medoruma in his fictional texts takes them up, too, but avoids using them in an essentializing way. Instead, it becomes clear that 'Okinawan traditions' do not function anymore. In "Mabuigumi", for example, Uta obviously represents 
the shamanistic yuta who, however, turns out to be completely powerless: Her attempts to heal and to save ultimately are unfruitful (Yonaha 2006: 13).

In "Suiteki", too, Tokusho's wife Ushi represents cultural traditions. She tries, for example, to treat Tokushō with traditional healing methods (Medoruma 2000 [1997]: 263) and wonders whether her failure in doing so might be related to some misbehavior on her part - but she cannot find an explanation, since she "never failed to participate in the village religious rites and always looked after her family's ancestral altar" (Medoruma 2000 [1997]: 257). On the other hand, the character of Dr. Öshiro (he is, by the way, the only one who does not speak the Okinawan dialect) stands for modernity and rationality, but at the same time for the fruitless efforts of modern (Western-inspired Japanese) medicine, since he is likewise unable to identify the reasons for Tokusho's condition. Ushi mistrusts modern medicine blatantly, but her visit to a yuta does not prove successful either, and she finally ends up "ashamed of herself for relying on a shaman in the first place" (Medoruma 2000 [1997]: 263).

By taking up the topic of 'Okinawan traditions' in this manner, Medoruma emphasizes diversity within Okinawa itself. In "Mabuigumi", too, Okinawa is no coherent entity but appears to be rather fragmented. Right in the beginning it becomes clear that Uta is positioned outside the village community as she deliberately does not take part in the morning gymnastics the village elders and the children perform collectively (Medoruma 2000 [1999]: 7). When Kotaro's body becomes inhabited by the crab, this triggers some dispute among the male villagers about whether to keep his condition a secret or make it public. And the fact that the journalists - one from "Yamato" (as Japan is referred to throughout the text), one from Naha - finally cause Kotaro's death highlights some Okinawans' collaboration with Japanese profit-seeking.

\subsection{Matayoshi Eiki: "Kahō wa umi kara"}

Matayoshi Eiki (*1949) had his breakthrough as a writer when he was awarded the Akutagawa Prize in 1995 for his novel Buta no mukui [The pig's retribution]. In his narratives he evokes local color by interspersing specific markers for 'Okinawan-ness': dialect, regional customs and manners, myths, and beliefs. However, Matayoshi seems to consciously address a broad, not only Okinawan readership, as his texts contain additional explanatory passages for a Japanese audience.

The short story "Kaho wa umi kara" [Fortunes by the sea] was published in the literary magazine Bungei Shunjū in 1998 and translated into English by David Fahy. It is set on a small, anonymous island (called T. Island), located offshore of the northern part of Okinawa's main is- 
land. Its protagonist is a young man by the name of Kazuhisa who at first is described as "pure and simple" (Matayoshi 2000 [1998]: 319; quotes are taken from the English translation), "unfocused and irresolute" (Matayoshi 2000 [1998]: 320), and "shy around strangers" (Matayoshi 2000 [1998]: 288). He marries young - at the age of 22 years and gets adopted by his wife's family, since there are no male successors. Before the wedding, under a deigo [Indian coral] tree, Kazuhisa has an oracle-like dream and thereupon senses that his marriage will not be a happy one (Matayoshi 2000 [1998]: 292).

Misako, his wife, is characterized as "relaxed and open around people" (Matayoshi 2000 [1998]: 288) and therefore as the exact opposite of Kazuhisa. She continues to work in the village office after marrying, while Kazuhisa, on the other hand, remains unemployed; he is responsible for cooking and tending to his father-in-law, a fisherman. Thus, in this small 'family' the conventional gender roles are reversed. Kazuhisa suffers from this and feels alienated:

He felt he could somehow put up with his life even if he didn't feel that he fit in; what he couldn't endure was if this were to continue into the next life. Given his shy, unsociable personality, he couldn't bear the thought that after death he would be for all eternity among complete strangers in Misako's family tomb. (Matayoshi 2000 [1998]: 308)

In the beginning of the story, all of Kazuhisa's undertakings end up as failures: He hopes to get a job at the village office with Misako's help, but they don't employ couples (Matayoshi 2000 [1998]: 296-297). And when Kazuhisa sets out to fish with his father-in-law, he turns out to be absolutely inept, because on the fishing boat, an Okinawan sabani, he always gets seasick (Matayoshi 2000 [1998]: 302-307). This inability of his gets directly connected to the reversal of gender roles in the text: "'Whoever heard of a man getting seasick,' his father-in-law ridiculed him. 'Is this a woman that's married into the family?'” (Matayoshi 2000 [1998]: 304).

This first part of the story serves as an introduction to Kazuhisa's family environment; then the protagonist endeavors on an adventure, as one night, he meets two young women, Junko and her older sister Rie, on the beach. Rie works in a bar on the Okinawan main island, and the protagonist decides to visit her there. Since he does not have any money, he steals a goat from a relative in order to sell it to a restaurant on the main island. He then purloins his father-in-law's sabani and crosses the ocean. At his arrival he does not manage to sell the goat and takes it to Rie's instead. The next morning, they drive to a remote beach where 
Rie slaughters the goat; Kazuhisa assists her more or less involuntarily (Matayoshi 2000 [1998]: 339-343). Rie uses the meat to make soup which they eat together, and Kazuhisa stays another night at the bar. The following day, suddenly his father-in-law appears to take Kazuhisa home. Contrary to what might be expected, the protagonist does not get scolded - rather, for the first time, he seems to be taken seriously by his father-in-law:

'[...] you stealing that goat, hauling it in the sabani, selling it, buying a woman - having the spirit to do all that, well, it brought peace to my heart. It showed that being an adopted husband hadn't robbed you of your backbone.'

'I didn't buy a woman or anything like that.'

'Fine, fine, don't worry - I won't say anything to Misako.'

(Matayoshi 2000 [1998]: 353)

In the end, Kazuhisa's father-in-law takes him to Saburō, the owner of the dead goat, in order to apologize. During the conversation, he praises Kazuhisa's deed exuberantly:

'Isn't it great though, Pop? What Kazuhisa did - stealing that tough old goat to get money for a woman. Quite impressive. Wouldn't have thought he had it in him, to tell you the truth.'

$[\ldots]$

'We used to do that all the time back in the old days.'

'Yeah, those were good times back then, Pop.'

[...]

'That was a thing of beauty you did, Kazuhisa,' his father-in-law said $[\ldots]$

'Before he couldn't even get the sabani out there on his own,' his father-in-law continued. 'Really quite remarkable, wouldn't you say, Pop? And all the way to the main island, too. Really quite impressive.'

Kazuhisa wondered if it really had been such a thing of beauty.

(Matayoshi 2000 [1998]: 357)

This text clearly bears allusions to the classical initiation story. In the beginning, Kazuhisa is depicted as an ineffective weakling. By stealing the goat and the boat he discovers a hitherto unknown strength in himself and gains new self-confidence. Through his adventure he becomes a man and is accepted as such by the members of his family. The gender order which had been turned upside down from the start is restored in the end, and Misako gets put in her place by her father: 
'You stay here,' her father told her as he opened the door.

'But I want to apologize to Uncle Saburo, too.'

'This is no time for a woman to be butting in.'

'Alright. I don't know exactly what happened anyway.'

(Matayoshi 2000 [1998]: 356)

In the conversation between Kazuhisa's father-in-law and uncle Saburo, a return to 'old times' and Okinawan 'traditions' is evoked. The two men expect Kazuhisa to re-live their own past - but he only seems to do so at the surface. Actually, the greatness of his adventure is ironically called into question because he has not carried out any of the deeds he gets praised for: Neither did he "buy a woman" (Matayoshi 2000 [1998]: 353), nor did he kill the goat himself but merely assisted Rie in doing so.

In Matayoshi's narratives, local Okinawan elements are strongly emphasized. As markers for 'Okinawan-ness', amongst other things the following are mentioned in "Kaho wa umi kara": the deigo, gajumaru and kuwadīs $\bar{a}$ trees; the alcoholic beverage awamori and the three-stringed instrument sanshin which Kazuhisa's father-in-law plays; a special form of collective dance called kachāshī; holy places referred to as utaki where gods and ancestors are worshipped; a yuta which is consulted before Misako is born; old, traditional women's names like "Cow, Jug, Oven, Pot, and other animals and kitchen things familiar from daily life" (Matayoshi 2000 [1998]: 322); certain kinds of beliefs such as "Happiness, they say in Okinawa, is brought to people by the kami of Nirai-kanai, located across the sea" (Matayoshi 2000 [1998]: 331); and, of course, the making and the consumption of the pungent goat soup which doubtlessly appears quite exotic to a Japanese audience. Interestingly, it is also mentioned that Misako's "household could easily live off the enormous amount of money they received each year from the land leased to the U.S. military" (Matayoshi 2000 [1998]: 296). At the same time it is made clear that life on $\mathrm{T}$. Island offers no prospects for the younger generation - and since "there are no regular jobs on the island besides fishing" (Matayoshi 2000 [1998]: 302), most young people have left for the main island of Okinawa or even the larger cities in Japan.

Matayoshi by these means constructs 'Okinawa' as a space which clearly is different from 'Japan'. On the surface he seems to employ the very same stereotypes which can be found in Japanese films and literary works on Okinawa, but: In Matayoshi's works these elements are not romantically glorified but rather used in an ambivalent, sometimes ironical manner. Okinawan traditions ultimately lose their original meaning in "Kaho wa umi kara", and they obviously form no basis the young protagonist can refer to in defining his identity. This can, for example, be illustrated very well by Kazuhisa's relation to the deigo tree: 
He thought it right that he should, and then, one day, he sought the opinion of the kami. He was partly serious about this and partly just going through the motions; mostly he just wanted to put the responsibility on someone besides himself [...] There was an old, large non-flowering male deigo tree on the edge of the village. People said that the kami that came to rest there prophesied the future to anyone happening to fall asleep in the tree's shadow. Kazuhisa ordinarily cared little for such notions [...]. (Matayoshi 2000 [1998]: 291)

After having met Rie and her sister, Kazuhisa climbs this same tree and masturbates (Matayoshi 2000 [1998]: 321) - which points out even more that local 'traditions' and beliefs, for him, are only of limited importance.

Moreover, the narrative altogether seems to express a generation gap in which Kazuhisa represents young Okinawa (educated, but nevertheless without prospects), while his father-in-law stands for the old, traditional aspects of it. The latter wants Kazuhisa to be a fisherman, too, and thus to become like himself (Matayoshi 2000 [1998]: 301). It therefore seems that the older generation wants to go on living like before; the young are supposed to pass down the 'traditions' and keep the 'old Okinawa' alive. Looked at from the outside, young Kazuhisa seems to meet these demands; but in fact he does not believe in these 'traditions' and keeps an inward distance.

\subsection{Akahoshi Toshizō’s "Aisu bā gāru"}

Many literary works by writers from Okinawa after the turn of the millennium continue processing these constructions of a 'different Okinawa'. Some of them address problems the prefecture is facing such as the lack of educational and job perspectives for young people on the islands; and some seem to consciously write against the existing stereotypes as spread by the mainstream media productions of the Okinawa boom. In doing so, many young authors show playful and experimental tendencies.

One interesting example in which the mainstream picture of Okinawa as an island paradise is taken up and ironically reversed is the short story "Aisu bā gāru" [Ice bar girl] by Akahoshi Toshizō (*1974), for which he was awarded one of the most important regional literary prizes, the Shin-Okinawa-bungaku-shō [i.e., prize granted by the literary magazine New Okinawa] in 2004. The text tells the story of its narrator Misaki, who has just finished high school and dreams of leaving Okinawa. Unfortunately, she has failed the university entrance exams in Tokyo and 
therefore has to stay on the (unspecified) island - which is referred to throughout as kono shima - for at least one more year. In order to fill the time, she takes on a job as an ice-cream vendor.

From the outset, the narrator again and again reports on her wanderlust. Since she was a child she has dreamt about getting on board a plane to leave the island - and fly away as far as possible. Her strong desire to go to a university in Tokyo, which she continuously refers to as "eastern city" (higashi no tokai) (Akahoshi 2004: 144; own translation), is connected to this dream. As a matter of fact, in the end a "fantasy plane" (maboroshi no hikōki) (Akahoshi 2004: 138) stands by to take everybody away who chooses to go aboard. Misaki decides not to fly away when she detects the ghost of her dead sister on the airfield outside. Just before, her parents had disclosed to her that her real family had died on a journey and that afterwards they had raised Misaki as their own child. On the airfield Misaki can talk to her deceased family and subsequently faints, blinded by the lights of the plane's take-off. The next day, everyday life on the island continues as before.

In his story, Akahoshi obviously plays with popular stereotypes on Okinawa and parodies them, thus questioning the image of Okinawa as a dream island. The author de-mystifies Okinawa by describing banal everyday life. Actually, Misaki's reality is in no way different from that of a high school student in Tokyo who fails the university entrance exams. In Okinawa, too, boredom, mundane problems and tragedies exist. While tourists and dropouts from the Japanese main islands seek comfort in Okinawa, the Okinawan protagonist dreams of setting out on a journey into the opposite direction. For her, it is exactly the otherness of Tokyo which is appealing.

A very important characteristic of the narrative lies in the fact that seeming contradictions nevertheless do coexist: Normality and the extraordinary permeate each other; reality and fantasy become blurred. The protagonist is different from her fellow islanders, but nevertheless the same. Misaki loves her parents but is also angry with them. She likes to live on the island but wants to leave. She explains this as follows:

'Some day I'm going to leave. It is not that I hate this island or my schoolmates. But I will definitely show them that I oppose their sense of values'.

Their sense of values $=$ the island we are living on is a paradise which abounds with humanity, and we'll stay in this place we love all our lives.

Probably this is how most people think. And they are right. Perhaps this is the best place to live. An island in the south, to which more and more people from the cities are continually relocating, 
and where the population is therefore increasing year by year. An island, surrounded by a beautiful ocean and with a blue sky. Our perfect island nobody ever complains about.

Once in a while I happen to get completely mad with this island which is loved by everybody so absolutely [...]

My schoolmates could not understand the anger I felt.

I have always wanted to go somewhere far away. Since I went to high school which was located nearby the airport, I had watched the planes on my way back home. I thought: I want to fly far away, preferably to the end of the world. (Akahoshi 2004: 141)

As these lines already suggest, Akahoshi in his text does not only create a reversal of the Japanese 'Okinawa craze'; another central theme of "Aisu bā gāru" is that of being different. Many small episodes differentiate Misaki, for example, from other young women: She always is so hungry that the dishes served for women at lunchtime are not enough to satisfy her appetite (Akahoshi 2004: 137). She also is the only girl in her class who, after graduation, has to spend one year as a rōnin. Interestingly, she does not view this as something negative; on the contrary, she states: "Everyone else has forgotten to pursue their dreams, has thought about some kind of band aid solution, and has passed, one after the other, thanks to recommendation" (Akahoshi 2004: 140). But not only Misaki as an individual is depicted as 'different' from her environment; she also perceives her whole family as divergent because of the mysterious disappearance of the little girl who later turns out to be Misaki's dead sister.

Another important character who highlights the theme of 'difference' in this story is Gen, a homeless man, whom Misaki befriends (this friendship, again, differentiates Misaki from her classmates [Akahoshi 2004: 149]) - and who is the one who tells her about the arrival of the fantasy plane. At the same time, Gen is not even the 'typical homeless person', since he is educated far above average - as a young man he had been a student at prestigious Waseda University in Tokyo (Akahoshi 2004: 136). And Gen also is different from his fellow Okinawans, because his father would not allow him to use the unprestigious local shimagotoba [island language]. Interestingly, he shares his inability to use and understand it correctly with Misaki (Akahoshi 2004: 159).

Toward the end of the story, though, Misaki has to realize that she might not be so different from everybody else, after all. She is surprised to see hundreds of like-minded people at the airport where the fantasy plane is waiting, and when Gen explains that "[e]verybody has to deal with one problem or another", she confesses: "I see. I have always 
thought it was only me. In a strange way that must have made me feel superior" (Akahoshi 2004: 160).

The fantasy plane is a means to leave the island, but at the same time it is a space between "this world and over there" (Akahoshi 2004: 157) where Misaki can talk to her dead parents and sister. Afterwards, there seems to be no immediate necessity to leave anymore. This suggests that another central theme the text deals with is the growing-up of its protagonist. When Misaki recognizes and comes to terms with her (long buried) family history, she might also be reconciled with her roots and identity.

In the end, Misaki stays on the island for one more year; she states, though, that she still wants to pursue her plans to go to Tokyo. Before, she only had wanted to escape into a fantasy world (Akahoshi 2004: 153), but now, leaving the island is not escapism anymore (Akahoshi 2004: 167). The end of the story yields an interesting hint in this respect: Misaki wants to leave the "nice, warm, a little bit obnoxious island, and go to the cool, fresh city". Two sentences later the ice cream parlor where she works is described as "cool and fresh", too (Akahoshi 2004: 167). Tokyo and the ice cream parlor on this small Okinawan island share the same attributes then - which might raise the question whether a Tokyo might even be found in Okinawa itself.

\subsection{Tefu Tefu P.'s "Tatakai, tatakau, hae"}

Tominaga Naoya $(* 1976)$, another young author from Okinawa who writes under the pseudonym of Tefu Tefu P., won the Ryūkyū Shinpō tanpen shōsetsu-shō [i.e., prize for short fiction awarded by the newspaper Ryükyu Shinpō] with his short story "Tatakai, tatakau, hae" [Combat, fight, fly] in 2000.

Like in "Aisu ba garu" we encounter a female protagonist - the narrator Mikako - who finds herself at a crossroads in her life since she has just graduated from university. Again, the narrative is a coming-ofage story. Through several flashbacks the reader gets to know that Mikako's mother left when her daughter was only six years old, and the protagonist afterwards was raised by her strict grandmother. Every single instance of misbehavior by the little girl - and even later, when Mikako has become a high school student - is punished severely by the grandmother who regularly hits her with a fly swatter so hard that marks are left on her face. What the grandmother interprets as misbehavior, however, is quite trivial: Mikako gets scolded and hit for example when she does not finish her meals, forgets to close the toilet lid, sleeps or gets up too late, talks too loud or plays outside too long (Tefu Tefu 2003 [2000]: 202). The reasons for this kind of severe physical abuse remain 
unclear; but for Mikako the scars on her body symbolize that she is her grandmother's property (Tefu Tefu 2003 [2000]: 202), and she compares her scars with the traditional hand tattoos of Okinawan women called hajichi (Tefu Tefu 2003 [2000]: 202).

One day, a swarm of combat flies kills the grandmother by emanating poison and acid. But even after her death she continues to haunt Mikako who, when being beaten (in her imagination?), shows the same physical signs as before: a red swelling. Mikako herself explains "I sensed a sharp pain on my left cheek. It burned like fire" (Tefu Tefu 2003 [2000]: 201).

Mikako's mother for the most part of the story plays a role only on the rare occasions when they talk to each other on the telephone. Usually these scenes culminate into a catastrophe, as Mikako begs her mother to take her home and afterwards gets beaten by her grandmother only the more. The mother apparently does not (or cannot) help - and her father is completely absent. Only after the death of the grandmother, Mikako learns that her parents had separated and that it had taken them ten years to finally get divorced - which is given as the reason why she was taken in by her grandmother on her father's side (Tefu Tefu 2003 [2000]: 210). Later, when she starts living with her mother again, she does not feel comfortable and takes the first opportunity of moving into her own apartment as soon as she enters university.

The grandmother who is referred to by Hino Keizo (Hino et al. 2003: 292) as onibaba (which in this context might best be translated as "devilish old woman") obviously symbolizes the power of 'traditions'. This is highlighted by the fact that throughout the text she uses heavy dialect which Mikako as a little girl is not able to understand and only gradually learns herself. These dialect passages are followed by translations into standard Japanese which are given in brackets. The text also contains some additional information which connects the grandmother with a pre-modern lifestyle - such as the fact that her house is located in a rural area and that there is no television set in the household (Tefu Tefu 2003 [2000]: 206).

The rules of conduct which the grandmother proclaims seem to have no special meaning - they might reflect just the attempt to keep up a certain order of things. Mikako as a student is not allowed to return to her apartment later than 8 p.m. (since this is the time her grandmother's ghost always appears) or meet and bring home any friends. Adhering to these rules makes normal life impossible and isolates Mikako from other people: She cannot maintain friendships, find a boyfriend and, due to the strict curfew, cannot even hold down a job after graduation.

Mikako's absent parents, in contrast, might represent the generation which in the process of passing on 'Okinawan traditions' - such as, for example, the use of the regional language - has been largely skipped. 
The motif of the 'incomplete family' might also reflect another widespread aspect of Okinawan reality, namely that children are often left behind to be raised by their grandparents; usually, though, this is due to the desolate economic situation which forces many people to leave in order to find work on the Japanese main islands. What is sure is that in "Tatakai, tatakau, hae" the grandmother does bear some kind of grudge against her daughter-in-law and tries to cut her off completely from Mikako; several times she also insists that Mikako is her own daughter whom she therefore raises on her own (Tefu Tefu 2003 [2000]: 204 and 209). Thus, in a sense, a kind of fight between the two older generations about their influence on the youngest one is taking place in this story.

Mikako tries to free herself from the unbearable situation of being tyrannized by her dead grandmother by a symbolic act: At first she believes that she needs to find the fly species that killed her grandmother. When she cannot manage to do so, she instead decides to draw a picture of the combat fly as a substitute and plans to use it as an amulet. When her dead grandmother detects what Mikako has planned, though, she destroys all existing pictures. The next day, Mikako has a combat fly tattooed on her left breast - and with this, the dead grandmother finally stops appearing. Mikako emancipates herself from both her grandmother and mother, becomes an adult and turns into a combat fly herself who can bravely face her environment. When she leaves for work the first day, she states: "From now on I am a combat fly, I will fight, I will do what I want. I will push my enemies out of the way" (Tefu Tefu 2003 [2000]: 214). She looks into the mirror and recognizes that her eyes have a blue sparkle to them (which alludes to the blue eyes of the fly described in the text several times) and that now there is something wild and terrifying about them (Tefu Tefu 2003 [2000]: 214). Thus, in this story the body appears as the site where conflicts with 'tradition' are carried out.

In this text the author subverts the stereotypical image of the strong but understanding and always good-humored Okinawan $o b \bar{a}$ [granny], who kind-heartedly supports those around her, an image which can be found in almost every single mainstream production. ${ }^{8}$ As a personification of the "old Okinawa' ${ }^{9}$ she rather appears to be a curse of which one has to free oneself. As it remains ambiguous whether the deadly combat flies actually existed, they might also be interpreted as the protagonist's concentrated desire for revenge. Looking at it this way, it is Mikako who, herself representing a fly in danger of getting hit with the swatter, does away with her grandmother but, for several years to come, is still not liberated from her influence - even after her death.

Tefu Tefu P. refrains from using typical markers for 'Okinawan-ness' such as the beach, blue skies, subtropical vegetation, exotic animals as well as elements from local religion and folklore. In his text, we also do 
not find the otherwise omnipresent character of the yuta. In Medoruma's and Matayoshi's narratives, female characters bearing allusions to shamanistic practices are still mentioned, but already in a deformed way: In "Suiteki" and "Mabuigumi", the yuta stands for the loss of traditions; and in "Kahō wa umi kara" Rie is in fact endowed with yuta-like features as she is said to be able to tell the future, but this - next to her beauty - just explains why men feel attracted to her and thus has a sexual connotation.

Even though it can be deduced from the context that "Tatakai, tatakau, hae" is geographically located in Okinawa (mainly from the use of dialect by Mikako's grandmother), Tefu Tefu P. gives only very scarce information about the setting of his narrative. This reminds, in a way, of "Aisu ba garu" in which only the phrase kono shima [this island] is used throughout. Matayoshi's T. Island might have been a first step into the direction of consciously obscuring the setting; but whereas in "Kahō wa umi kara" some precise locations such as Motobu and Naha are given, an exact location cannot be identified in the works by the two younger authors.

The Okinawan regional language is used - and sometimes even addressed as a topic - in each of the works that were chosen for analysis in this paper. Medoruma uses dialect in his dialogues seemingly trying to make the characters appear more authentic. Okinawan language passages are not translated or explained. Matayoshi, in contrast, explains the Okinawan phrases he uses in standard Japanese. In "Aisu bā gāru" and "Tatakai, tatakau, hae" we finally encounter the conflict of some Okinawan characters with the local dialect: Misaki and Gen are differentiated from their environment because they cannot understand the real local language, and in Tefu Tefu P.'s story, the narrator does not know the local language, either; only by living with her grandmother, she learns to understand it over the years.

\section{Conclusion}

Japanese constructions of Okinawan-ness in mass media clearly contain a mix of what Stuart Hall has called strategies in dealing with 'difference', strategies such as foreignness, exclusion, repression, projection, exoticism, orientalism, fetishization and pathologization. Okinawa is frequently represented as Japan's exotic other, as an "eternally festive place' from which the people of mainland Japan seek comfort and onto which they project their nostalgia for a utopian vision of Japan's premodernity" (Kō 2006: 157). On the other hand, the negative aspects of Okinawan 'reality' (e.g., the 'base burden', as well as dealing with pov- 
erty, unemployment and memories of wartime experiences, etc.) are completely left out of the picture.

Indeed, not only the Japanese mainstream media and popular literary works but also filmmakers and writers from Okinawa all refer to the same markers for 'Okinawan difference': local customs and manners, the Okinawan dialect, and diverse other, ever recurring elements which are deemed typical for Okinawa. Japanese and Okinawan representations thus do not seem to be of a profoundly different nature when looking only at what is said about Okinawa. Do constructions of Okinawa as 'different' by local authors, then, challenge the dominant idea of Japan's cultural homogeneity at all? Or are these images, on the contrary, signs of a certain self-exoticization?

As a matter of fact, when looking at what is not mentioned and how 'Okinawan difference' is staged, Japanese and Okinawan representations actually tend to diverge from each other. For example, the manner in which local color elements are employed by writers from Okinawa seems to be very deliberately directed against the dominant, exoticizing discourse on Okinawan difference. Narratives by authors from Okinawa since the mid-1990s frequently seem to question the assumption that there is one shared reality, instead creating plurality. Especially striking are the frequent adoptions of magical elements, but also the obvious attempts to counter the Japanese presupposition that there is something like one Okinawan identity, by creating many different versions of how Okinawa might be. Moreover, difference vis-à-vis Japan is constructed by addressing inconvenient topics which usually remain excluded from the hegemonic Okinawa discourse: The Okinawan population's specific experiences with the war, occupation and continuing presence of U.S. military facilities on the islands, but also the lack of future perspectives for young people, and the economically difficult living conditions. Authors from Okinawa thus ironically invert the image of Okinawa as healing island paradise and deconstruct Okinawan 'traditions' which are essentialized and idealized elsewhere. Despite the heterogeneity of their different approaches, they all construct images of Okinawa which are more complex and ambivalent than the usual representations of Okinawa from a Japanese main islands' perspective.

However, writers from Okinawa are, for the most part, positioned outside the dominant discourse. Their access to resources of self-representation clearly is limited, while the power to represent Okinawa on a wide scale seems to lie entirely in the hands of the Japanese mainstream media. The four authors from Okinawa treated in this paper thus construct Okinawa as different from mainland Japan and, in doing so, employ methods different from those in mainland Japanese constructions of 'Okinawan difference' - but at the same time, their constructions 
cannot unfold an equally wide impact so far. It might be not so important, eventually, whether an author has got an Okinawan or Japanese main islands' background; instead, the differences in representation rather seem to be related to the question whether the writer has access to the popular market or stays within the scope of 'minor literature'. ${ }^{10}$

Concerning the relation between the concept of the (Japanese) nation state and that of inner (cultural) diversity, Gaynor Macdonald makes an instructive statement: "A true recognition of cultural diversity [...] implies that it [the nation] recognises the contradictions, problems, conflicts and violences that are produced in the struggles of peoples to share their world" (Mcdonald 1995: 313). If this is the case, the Okinawa boom which has undoubtedly contributed to a more positive image of Okinawa on the Japanese main islands in recent years - might just be another example of 'cosmetic multiculturalism' which "remains essentially a form of exterior decoration that does not demand major structural changes to existing institutions" (Morris-Suzuki 2002: 171). The hierarchical relation between (Japanese) popular constructions of Okinawa and their (Okinawan) counter-images demonstrate that 'Okinawan difference' is not really accepted yet - and it will not be as long as Japanese mainstream constructions of Okinawa place emphasis only on a soft sell and continue to neglect Okinawa's problems and contradictions.

Ina Hein (ina.hein@univie.ac.at) received her Ph.D. as a member of the doctoral program "Identity and Difference. Gender Constructions and Interculturality" at the University of Trier, Germany. Her dissertation on gender construction in the literature of popular Japanese women writers was granted the university's award for best Ph.D. thesis. Currently she is professor of Japanese Studies at the University of Vienna, Austria. Her research covers modern Japanese literature, cultural studies, and gender studies.

\section{Notes}

* I would like to thank the two anonymous reviewers of this paper for their stimulating comments. My special thanks also go to the issue editors for their careful reading and valuable suggestions, which greatly helped me in improving this paper.

1. The homogeneity doctrine - as it manifests itself in the nihonjinron [discourse on the Japanese] - became widely accepted only after 1945. As Oguma Eiji (2002) shows, between 1868 and 1945 a completely different policy of defining 'Japan' was predominant, namely as encompassing different (ethnic) groups of people (who, nevertheless, were assumed to share lineage with the Japanese, and at the same time were subjected to a strict Japanese assimilation policy). This 'mixed nation theory' was adopted in order to justify the Japanese colonization of other Asian countries. 
2. First steps to create a more attractive image of the Okinawan islands can be traced back to the immediate post-reversion years, when Japanese tourism to Okinawa was being actively promoted. Tada Osamu identifies the International Maritime Exhibition, which was held in Okinawa from July 1975 to January 1976, as a central element in this process. When the number of tourists dropped again afterwards, the Okinawa kanko kyanpen [Okinawa tourism campaign] was launched. During the course of this, Dentsū decided to eliminate everything that could create negative associations (like, for example, memories of the Pacific War) from the image of Okinawa and instead focused on strengthening positive aspects in order to make Okinawa more sellable - for more detailed information see Tada (2007 [2004]). Even though these efforts can be seen as first steps towards the creation of an exotic and idealized Okinawa for the tourism industry, it nevertheless took two more decades for the image of Okinawa as an island-paradise to establish itself as a solid part of Japanese mainstream media.

3. My understanding and use of the terms 'Okinawa' and 'Japan' might need some clarification here. Of course, neither 'Okinawa' nor 'Japan' are homogeneous entities; rather, they are multiply diversified within. The discourse on Okinawa's relation to Japan, though, is dominated by a sharp division between 'Okinawa' (uchinā) and 'Okinawans' (uchinānchu) on the one hand, and 'Japan' (yamato) and 'Japanese' (yamatunchu) on the other. Therefore, these terms are treated as discursively produced categories throughout this paper.

4. See Shinzato (2003: 290-291). The author identifies music, theater, comics, television and radio programs as elements central to the Okinawa boom. Generally, its beginnings are traced back to the mid-1980s when Okinawan music started to become popular on the Japanese main islands.

5. Examples are the morning series Churasan (produced by NHK, 2001) as well as the TV series Dr. Kotō shinryōjo [Dr. Kotō's clinic] (Fuji, 2004 and 2006), Ruri no shima [Ruri's island] (NTV, 2005), and Honjitsu mo hare. Ijō nashi [Nice weather again today. No special incidents] (TBS, 2009).

6. See, for example, Molasky's (2003: 162-164) discussion of literature from Okinawa within the categories of minority literature and regional literature. Bhowmik (2008: 2-3; 9-11) takes into account the concept of minor literature (in the sense of Gilles Deleuze and Felix Guattari) as well.

7. It is an Okinawan belief that a mabui - i.e., the "spirit (of a person who is alive)" (Uchima and Nohara 2006: 255) - can leave the body when this person is in shock or otherwise emotionally weakened.

8. The best example would be grandmother Hana (in the television series Churasan), played by Taira Tomi, who represents this type of $o b \bar{a}$ in several other productions about Okinawa as well.

9. Yonaha Keiko shows that Okinawan women in literature - also that by Okinawan authors - usually are represented as lively and energetic (Yonaha 2006: 7), as preservers of traditions, guardians of the family or the community, and thus as embodiments of Okinawa as a whole (Yonaha 2006: 9).

10. Tada Osamu expresses a similar assumption when comparing the films of Kyotoborn director Nakae Yaji with those of the Okinawan filmmaker Takamine Gō (Tada 2004: 73).

\section{References}

Akahoshi, Toshizō. 2004. Aisu bā gāru. Fu Okinawa bungei nenkan [Yearbook of Okinawan literature], 132-166. Naha: Okinawa Taimususha. 
Allen, Matthew. 2002. Therapies of resistance? Yuta, help-seeking, and identity in Okinawa. Critical Asian Studies 34 (2). 221-242.

Bhowmik, Davinder L. 2003. Plain water with a twist of lime(stone): Magical realism in Medoruma Shun. Proceedings of the Association for Japanese Literary Studies 4. $311-318$.

Bhowmik, Davinder L. (ed.). 2008. Writing Okinawa: Narrative acts of identity and resistance (Routledge Studies in Asia's Transformations). London \& New York: Routledge.

Bronfen, Elisabeth \& Benjamin Marius. 1997. Hybride Kulturen. Einleitung zur angloamerikanischen Multikulturalismusdebatte [Hybrid cultures. Introduction to the Anglo-American debate on multiculturalism]. In Elisabeth Bronfen \& Benjamin Marius (eds.), Hybride Kulturen. Beiträge zur anglo-amerikanischen Multikulturalismusdebatte [Hybrid cultures. Contributions to the Anglo-American debate on multiculturalism], 1-29. Tübingen: Stauffenberg Verlag Brigitte Narr.

Hein, Laura Elizabeth \& Mark Selden. 2003. Culture, power, and identity in contemporary Japan. In Laura E. Hein \& Mark Selden (eds.), Islands of discontent: Okinawan responses to Japanese and American power (Asian voices), 1-35. Lanham: Rowman \& Littlefield Publishers.

Hino, Keizō, Tatsuhiro Oshiro \& Noboru Tsujihara. 2003. Senkōhyō [Commentary by the prize committee]. In Ryakya Shinposha (ed.), Okinawa tanpen shosetsusha - 'Ryakya Shinpo tanpen shosetsu-sho' jusho sakuhin [Short fiction from Okinawa - works awarded the Ryakya Shinpō Literary Prize] (Vol. 2), 273-299. Naha: Ryakya Shinposha.

Iwabuchi, Koichi, Osamu Tada \& Yasuhiro Tanaka (eds.). 2004. Okinawa ni tachisukumu. Daigaku o koete shinka suru chi [Standing frozen in Okinawa. Deepening university knowledge]. Tokyo: Serika Shobo.

Kiberd, Declan. 1996 [1988]. Inventing Ireland. The literature of the modern nation. London: Vintage.

Ko, Mika. 2006. Takamine Go: a possible Okinawan cinema. Inter-Asia Cultural Studies 7 (1). 156-170.

Maher, John C. 2005. Metroethnicity, language, and the principle of cool. International Journal of the Sociology of Language 175. 83-102.

Matayoshi, Eiki. 1998. Kaho wa umi kara [Fortunes by the sea]. In Eiki Matayoshi, Kaho wa umi kara, 5-91. Tokyo: Bungei Shunja.

Matayoshi, Eiki. 2000 [1998]. Fortunes by the sea. In Michael Molasky \& Steve Rabson (eds.), Southern exposure: Modern Japanese literature from Okinawa, 287357. Honolulu: University of Hawaii Press.

Mcdonald, Gaynor. 1995. The politics of diversity in the nation-state. In Gaynor Mcdonald \& John Maher (eds.), Diversity in Japanese culture and language, 291-315. London \& New York: Kegan Paul.

Medoruma, Shun. 1997. Suiteki [Droplets]. In Shun Medoruma, Suiteki, 5-50. Tokyo: Bungei Shunja.

Medoruma, Shun. 2000 [1997]. Droplets. In Michael Molasky \& Steve Rabson (eds.), Southern exposure: Modern Japanese literature from Okinawa, 255-285. Honolulu: University of Hawaii Press.

Medoruma, Shun. 2000 [1999]. Mabuigumi [Spirit recalling]. Tokyo: Asahi Shimbunsha.

Molasky, Michael. 2003. Medoruma Shun: The Writer as Public Intellectual in Okinawa Today. In Laura Hein \& Mark Selden (eds.), Islands of discontent. Okinawan responses to Japanese and American power, 161-191. Lanham: Rowman \& Littlefield Publishers.

Mori, Reiko. 1989. Kaminchu [Holy women]. Tokyo: Kodansha. 
Morris-Suzuki, Tessa. 1998. Japan. In Tessa Morris-Suzuki, Re-inventing Japan. Time, space, nation, 9-34. Armonk, NY \& London: M. E. Sharpe.

Morris-Suzuki, Tessa. 2000. Immigration and citizenship in contemporary Japan. In Syed Javed Maswood, Jeffrey Graham \& Hideaki Miyajime (eds.), Japan Change and continuity, 163-178. New York: Routledge.

Oguma, Eiji. 2002. A genealogy of 'Japanese' self-images. Melbourne: Trans Pacific Press.

Oguma, Eiji. 2006 [1998]. 'Nihonjin' no kyokai. Okinawa - Ainu - Taiwan - Chosen: Shokuminchi shihai kara fukki undo made [The boundaries of the 'Japanese'. OkTawa - Ainu - Taiwan - Korea: From colonial rule to reversion movements]. Tokyo: Shinyosha.

Okuda, Hideo. 2005. Sausu baundo [Southbound]. Tokyo: Kadokawa Shoten.

Shinjo, Ikuo. 2003. Okinawa bungaku to iu kuwadate. Katto suru gengo, shintai, kioku [The enterprise of Okinawan literature. Language, body and memory in conflict]. Tokyo: Inpakuto Shuppan.

Shinzato, Rumiko. 2003. Wars, politics, and language: A case study of the Okinawan language. In Mirjana N. Dedaic \& Daniel N. Nelson (eds.), At war with words (Language, Power and Social Process 10), 281-313. Berlin \& New York: Mouton de Gruyter.

Siddle, Richard. 1998. Colonialism and identity in Okinawa before 1945. Japanese Studies 18 (2). 117-133.

Tada, Osamu. 2004. Okinawa ni okeru 'Okinawa' imēji no shohi [The consumption of images of 'Okinawa' in Okinawa]. In Koichi Iwabuchi, Osamu Tada \& Yasuhiro Tanaka (eds.), Okinawa ni tachisukumu. Daigaku o koete shinka suru chi [Standing frozen in Okinawa. Deepening university knowledge], 66-76. Tokyo: Serika Shobo.

Tada, Osamu. 2007 [2004]. Okinawa imeji no tanjo. Aoi umi no karuchuraru sutadtzu [The genesis of images of Okinawa. Cultural studies of the blue sea]. Tokyo: Tokyo Keizai Shinposha.

Taira, Koji. 1997. Troubled national identity. The Ryukyuans/Okinawans. In Michael Weiner (ed.), Japan's minorities. The illusion of homogeneity, 140-177. London \& New York: Routledge.

Tefu Tefu P., 2003 [2000]. Tatakai, tatakau, hae [Fight, fight, fly]. In Ryakya Shinpōsha (ed.), Okinawa tanpen shosetsu-sha - 'Ryakya Shinpo tanpen shosetsu-sho' jusho sakuhin [Short fiction from Okinawa - works awarded the Ryukyu Shinpō Literary Prize], Vol. 2, 195-214. Naha: Ryakya Shinpōsha.

Tōkeikyoku (Japanese Statistics Bureau). 2008. Report on internal migration in Japan $>$ Annual report > Yearly > 2008: E-stat portal site of official statistics of Japan. http://www.e-stat.go.jp/SG1/estat/ListE.do?lid=000001054292 (accessed 2 June 2009).

Uchima, Chokujin \& Mitsuyoshi Nohara. 2006. Okinawa-go jiten. Naha hōgen o chūshin $n i$ [Dictionary of the Okinawan language. Centering on the Naha dialect]. Tokyo: Kenkynsha.

Uemura, Hideaki. 2003. The colonial annexation of Okinawa and the logic of international law: The formation of an 'indigenous people' in East Asia. Japanese Studies 23 (2). 107-124.

Yokoyama, Manabu (ed.). 1980. Ryūkyū shozoku mondai kankei shiryō [Materials concerning the question of where Ryūkyū belongs], Vol. 2. Tokyo: Honpō Shobō.

Yonaha, Keiko. 1996. Okinawa no shōsetsu/engeki-shi: Fukkigo [A history of Okinawan novels and plays: post-reversion]. In Jun Kubota (ed.), Ryūkyū bungaku, Okinawa no bungaku (Iwanami Kōza: Nihon bungaku-shi 15), 205-220. Tokyo: Iwanami Shoten. 


\section{Ina Hein}

Yonaha, Keiko. 2006. Okinawa bungaku no hyosho - sono joseizo o toshite miru 'sengo Okinawa' [Postwar Okinawa as seen through female characters in Okinawan literature]. In Okinawa Bungaku Kenkynkai (ed.), Gendai Okinawa bungaku no seidoteki jasosei to hondokankei no naka de no Okinawa-sei ni kansuru kenkyaOkinawa bungaku o torimaku media, kisobunka, josei [Studies on the institutional multilayeredness of contemporary Okinawan literature and Okinawan-ness in relation to Japan - media, culture, women and Okinawan literature], 5-17. Tokyo: Morimoto Insatsu.

Yonetani, Julia. 2000. Ambiguous traces and the politics of sameness: Placing Okinawa in Meiji Japan. Japanese Studies 20 (1). 15-31.

Yoshimoto, Banana. 2004. Nankurunai [What will be will be]. Tokyo: Shinchosha. 